\title{
BEYOND THE MODERN SHAPES OF THE EQUALITY PRINCIPLE. NOTES FOR A TRANSITION
}

\section{MAS ALLÁ DE LAS FORMAS DEL PRINCIPIO DE IGUALDAD. NOTAS PARA UNA TRANSICIÓN}

\section{José María Seco Martínez}

Universidad Pablo de Olavide, Sevilla, España

jmsecmar@upo.es

Resumen: La igualdad, como proceso histórico de emancipación humana, trasciende el plano estrictamente jurídico/formal. Además, se ve reforzada por la voluntad "histórica" de democratizar la sociedad y mejorar la vida de las personas. Esta es la dimensión materialista del principio de igualdad, en esa disposición ética e histórica basada en la producción y desarrollo de la justicia social como criterio y principio de actuación. Los derechos humanos y la democracia, con sus prácticas y tradiciones de lucha, no pueden entenderse hoy sin la idea de igualdad como principio necesario. Los derechos humanos siempre han estado vinculados a procesos de reacción contra las desigualdades. Los derechos humanos, que son derechos y que son humanos, son siempre acciones que se refieren a seres humanos necesitados. El hecho de que hayan sido concebidos formalmente bajo el paraguas de la razón normativa no presupone que deban ser concebidos exclusivamente como derechos individuales, que exigen su realización en el futuro, como horizontes de posibilidad, sino como formas de vida que hacen factible la existencia humana -con dignidad- para todas las personas. La idea de igualdad no es, por tanto, posible sin este juicio material de la existencia.

Abstract: Equality as a historic process of human emancipation, transcends the strictly legal/formal plane. Furthermore, it is enhanced by the "historic" willingness to democratise society and improve people's lives. This is the materialistic dimension of the principle of equality, this ethical and historical "willingness" based on the production and development of social justice as a criterion and principle for action. Human rights and democracy, with their fighting practices and traditions, cannot be understood today without the idea of equality as a necessary principle. Human rights have always been linked to processes 
of reaction against inequalities. They have been and remain a reaction to any kind of oppression and/or domination, because human rights, which are rights and are human, are always actions that refer to human beings in need. The fact that they were formally conceived under the umbrella of normative reasoning does not presuppose that they should be conceived exclusively as individual rights, which demand fulfilment in the future, or even as horizons of possibility (idealistic vision), but as a ways of life that make human existence - dignified existence - feasible for all people. The idea of equality is, therefore, not possible without this material judgement of existence.

\section{Introduction}

Throughout the history of humanity, vastly differing reflections have been theorised about the notion of equality. From Antiquity to the present day, the experience brought by years has been punctuated by diverse conceptions and understandings of equality. This diversity of approaches or perspectives on equality has given rise to the idea held by many authors that equality is a vague or ambiguous concept, one that can be understood in very different ways.

In its traditional meaning, held by Ancient Greek philosophers such as Plato and Aristotle, and later St. Thomas, the concept remains ambiguous in its content. Since then, however, the concept has evolved to reach a decisive meaning in the present day for the legitimisation of political processes.

In ancient Greece, the term Isonomy (iøovouía) referred to what we now know as "equality before the law" and was decisive in the emergence of future Athenian democracy. It basically represented equal civil and political rights among citizens. It was the political metaphor that best synthesised the idea of democracy, as opposed to the unchecked prerogatives of tyranny. Interestingly, it was most used at that time to designate and/or define democratic regimes, before the concept of democracy became generalised in the collective imaginary. Plato offered the first approach to the idea of economic equality among all subjects as a fundamental value for coexistence. Moreover, the Athenian model of democracy was resolutely functional to the idea of equality. This is inferred by Aristotle himself when he defines democracy as the system in which isonomy (equality before the law) coincides with isocracy (equality in decision-making or before power), and isogony (equality of all to intervene in administration, with the same limitations for access to citizenship status) ${ }^{1}$.

This philosophy, widespread in GrecoRoman society, was gradually conceived with the passing of time and the arrival from Christianity of the idea of cosmopolitanism², by virtue of which all

1. Aristotle himself says, "it is thought that justice is equality, and so it is, though not for everybody but only for those who are equals; and it is thought that inequality is just, for so indeed it is, though not for everybody, but for those who are unequal". Aristotle, Politics III, 9, 1280a

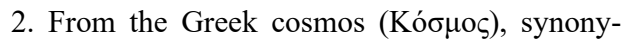
mous with universe, and polis (Пó $\lambda 1 \varsigma$ ), synonymous with city, although this identification should not detract from the semantic complexity of the concept of cosmopolitanism, which was historically varied until it led to the Enlightened idea of moral universalism. It has always been a constant in Western tradition, but it has also been a polysemic concept, forged over time. On the 
human beings were equal, as children of $\mathrm{God}^{3}$. The concept of equality proposed by Christianity is, therefore, a concept of theological equality, not material equality, understood as a condition of possibility for human beings. That is, for most medieval Christian theologians, "theological equality" was perfectly in harmony with social inequality.

However, Christianity had a framework of understanding that was ethically close to the idea of justice, among other things, because it was directly rooted in the Law of Moses. So it received from this Law, as part of the latter's legacy, the tradition of mišpat, an interesting legal concept related to the idea of equality before the law and the judicial protection of the poor and oppressed. In ancient or medieval Christian thought, there was no explicit reference to the idea of equality. There was, however, an ethical recognition of the idea of justice, which emanated from

concept of cosmopolitanism, see Scuccimarra L., I confini del mondo, Il Mulino, 2006. In this step, the hominum societas described by Cicero in de Officiis is freed from its primeval meaning as a set of social relations, to adapt to the requirements of an increasingly complex model of multiple and contradictory relations, where individual affiliation helps to strengthen universal affiliation. The "great society of humanity" was inverted, during the " 700 , through the ethics of enlightened politics that makes it more complex, through interaction between the universal and the particular, which provided the foundation for Cicero's ideal of a strict ethical hierarchy based on the level of inter-subjective proximity ( Id., p.. 416).

3. St. Paul's Letter to the Galatians states: "You are all God's children through faith in Christ Jesus....There is neither Jew nor Greek; there is neither slave nor free; nor is there male and female, for you are all one in Christ Jesus (...)" (St. Paul, 3, 26, 29). this Jewish tradition ${ }^{4}$. Thus, Christian philosophy gradually designed a cognitive framework, which was assumed by Roman law, progressively improving the situation of slaves, children and women, whose conditions of possibility were now higher than in Roman society. Such ideas were later developed by the Fathers of the Church (St. Basil, St. John Chrysostom, St. Athanasius, etc.), giving way to a more social and limited sense of ownership and law.

Later, St. Thomas Aquinas would underpin the foundations of the medieval legal order, taking up the ideas of Aristotle and St. Agustin of Hippo and stating that, in addition to the law imposed by men, there is a natural law, which no man or government can ignore. Christian doctrine then postulated the existence of two distinct kingdoms, temporal and spiritual, each unto its own. Faced with the problem of reconciling individual and social interests, St. Thomas Aquinas stated, in his Summa Theologica, that if there was a conflict between the social and the individual, the common good should prevail, which was the appeal of the egalitarian demand of Christianity. However, if, on the contrary, the conflict affected the private sphere of the human being and his salvation, then the good of that person would prevail over that of society. In this respect, if there is a clear conflict between law and natural law, the existence of a "right of resistance" against the arbitrage of rulers emerges from St. Thomas' thought. That is the prelude to political equality.

4. The New Testament is full of parables and/or teachings about injustice, intolerance or selfishness in the use of goods 
With the advent of modernity and its processes of democratisation (equality and pluralism) and secularisation (desacralisation, polytheism of values, etc.), the concept of equality takes on a new dimension. However, despite the performative and transformative potential of both processes, the fact is that both would soon end up being subordinated, according to the logic of capital, to restrict the rise of new emancipations that competed for access to the social space conquered by the bourgeoisie. It is important to insist on this point, especially in terms of what it does to modern processes of secularisation, because if we are to restore the materialistic dimension of the principle of equality, we must first elucidate the fact that such processes did not succeed in de-sacralising historical reality.

Therefore, with the revolutionary processes of modernity, the idea of equality assumes (only superficially) the absence of a natural or external (i.e. metaphysical) foundation, finally revealing its most conventional and historical character, which is now expressed through the words of the Law. The field of equality no longer dissolves in the theological plane, but in the order of words. And as words, these are no longer divine (deicide), but human, although they are uttered by another, equally metaphysical, "creative subject." Thus, the struggle for legal equality breaks into the socio-cultural context of modernity (18th Century) and is now synthesised in the recognition of the inherent and inalienable rights of men. The 1776 and 1789 Declarations of Rights are the culmination of this new vision of the idea of equality, which now crystallises in the expression "Men are born and remain free and equal in rights", in accordance with article 1 of the 1789 Declaration of the Rights of Man and the Citizen.

Thus, the egalitarian plan of modernity, which proclaimed legal equality and demanded, initially at any rate, economic equality among all subjects, would soon become connected to individualism. This fact and the proprietary logic that gave rise to the new hegemonic socio-economic order (the bourgeois) deactivated the emancipating potential of the democratic principle. Thanks to bourgeois capitalist domination and positivist ideology in the sciences, the modern notion of equality ends up being an idea of hypostatised formal - equality.

In other words, the idea of equality escapes from the realm of the human, that is, from the real praxis of men (with their problems and needs), to dock in an idea of equality that is ostensibly neutral and objective, only predicable for equally formalised subjects, i.e. abstract subjects, without needs and away from the concrete praxis of human beings and their contingencies. We are referring here to the subject of law, in other words, a legal person. A subject who sympathises little with human beings, as subjects in need, because he neither identifies with all subjects (only with the citizen), nor recognises their problems.

The convergence of modernity/capitalism was the result of the colonisation of modernity by capitalism. There is, therefore, a shift in the category of the subject: from man to citizen - a good bourgeois citizen and from this to legal person, as a focus for the imputation of rights and duties, that is, with the capacity to enter contracts and be legally bound. A type of subject that is not only predictable for citizens but also for businesses. 
With this shift in the figure of the subject, the idea of equality takes on two dimensions: formal equality and material equality. The first focuses on the principle of equality before the law, while moving away from social praxis (contingency). The second crystallises in the social struggles for substantive equality or the social rights of individuals, particularly in the second half of the twentieth century, which is when we gain an awareness of universality and humanity, especially in relation to the rights of individuals (human rights).

In short, the idea of equality must be understood as a historic process of emancipation. Equality is a product of human action. It is, therefore, part of the historical experience of building realities, which is always the subjective experience of the subjects who build them throughout history. Outside human action there is nothing in history. That is why social practices of equality are historical practices and, as such, despite the constraints of each time, they are located in this historic process of fighting for the equality of human beings.

\section{How the concept of legal equality is no longer the foundation of Human Rights (being considered not as rights, but as a way of life)}

As we have already seen, with the arrival of modernity and its egalitarian expectations, a system emerges for the regulation of social relations, based on the idea of legal equality, represented in a model of citizenship that presupposed, on the one hand, recognition of the inherent and inalienable rights of all men, and, on the other hand, the equality of all citizens before the law.

Equality is now, as it was then, one of the crucial problems of political legal thinking 5 . Equality is one of the central political categories of modernity and its processes (democratisation and secularisation), which flow back into an unprecedented model of citizenship. The replacement, on the one hand, of the ontological social bond (the Aristotelian zoon politikon) with a social bond instituted as the absolute foundation in the framework system of modernity, represented in the "individual" as a rational and disassociated subject (in law); and, on the other, the assumption of the idea of a nation - an idealistic and anonymous reflection of the bourgeoisie as a class - as the fundamental political unit - the backbone of the entire political system, which channelled the exercising of rights and ensured social loyalty crystallised in the figure of citizen (with "legal capacity" and in conditions of equality), as the only possible and conventional scheme for articulating relations within States, that is, as a means of legitimation and a mechanism for social integration within the community.

Thus, the idea of an individual as an absolute and instituted social foundation and the idea of a nation as a metaphysical entity, as the natural basis of the State not as one of its constituent elements - gradually weighted up a new (modern) way of thinking and prefiguring social relations, in contrast to the caste-based

5. As Fernando Rey points out, the legal concept of equality "is more powerful and dense than ever" See Herrera, J., "Legalidad: Explorando la nueva ciudadanía", in Campos de juego de la ciudadanía, Various Authors, El Viejo Topo, Barcelona, 2003. 
stratification of pre-modern or "irrational" societies. Modern society was born as an individualistic and patriarchal society, but above all as a society of autonomous and legally equal subjects - the egalitarian design of modernity thus becomes formal equality - defined as property owners and citizens.

However, this (flat and monist) scheme of citizenship, assembled in individualism and predictable only for abstract subjects, duly formalised in a status of equality as artificial $^{6}$ - borne of the arbitrary-idealistic fiction of the autonomy of will - as it was decontextualised, operates as an ontological status that presupposes not only the legal formalisation of rights, but also subjection to a specific legal-political status in the more territorial sense of its limits. As we will see, this is a formal concept of citizenship in which, although legal equality is assumed, exclusion prevails over inclusion, and even more so, regulation over emancipation. This classic concept of equality, so to speak, is defined from the acceptance of immovable and timeless preconceptions that condition it from start to finish, among other things, because it is rooted more in the static idea of formal equality or status than in that of the contract - which is similarly fictional and ideological. The defence of status is equivalent to consolidating a differential, fragmentary, complex and, therefore, hierarchical relationship between classes, communities and groups of citizens, which is explicit in structural but also functional dissimilarity to the demands of the current order, its powers and rights.

Formal equality is, therefore, the dimension of the idea of equality that has gained

6. See Barry P., Ser ciudadano, (translated by A. Mendoza from the original Deep Citizenship, Pluto Press, 1996) Sequitur, Madrid, 1999, p. 9 the most relevance in Western normative systems. It is basically identified in modern societies with the principle of equality of all before the law. Or, to put it another way, equal legal-political status is recognised for all subjects. In our normative systems ${ }^{7}$, the idea of equality is no longer understood as a higher value - a horizon of possibility for laws - but as a subjective right of all citizens vis-à-vis the State. That is what formal equality is all about. However, to ensure that the principle of equality before the law - we are all in the same situation visà-vis the effects of the law - is relevant and does not lose its object, "legal equality" (of which it is also a part) must also be equal in the application of the law (in identical situations, the application of the law will be the same). In other words, all citizens are equally subject to law enforcement procedures. Note that law and, therefore, rules are not an end in themselves; law is useful for the achievement of ends, and this gives it that characteristic "pragmatic" profile, which is synthesised in the search for "operability".

Hence, there can only be intelligence in law if the latter is contextualised, not only within the framework of conditions surrounding its legislative production, but also within the order of praxis, that is, its application. This is achieved through "procedural experience". The activity of jurists is directed not towards simply knowing, "but towards knowing

7. Ronconi L., and Vita, L., "El principio de igualdad en la enseñanza del Derecho Constitucional", in Academia. Revista sobre enseñanza del Derecho, Buenos Aires, no 19, 2012, pp. 31-62. See also Didier, M., El principio de la Igualdad en las Normas Jurídicas, Marcial Pons, Buenos Aires, 2011, pp. 11-19. 
in order to act through process"8, so the application of the same procedure to all citizens is not only a guarantee of procedural regularity with regard to the administration. Rather, it is a functional guarantee for our own model of State. It is, therefore, "an indispensable reference for the exercise of political power"9. Hence, it is appropriate to distinguish, within the conceptual framework of the principle of formal equality before the law, two different planes or senses, which nonetheless complement one another.

But if the notion of equality, beyond its formal dimension, is defined, as pointed out previously, as a historic process of emancipation, the idea of equality is not exhausted in terms of legal equality alone. On the contrary, it is enhanced and realised by the "historical" willingness to democratise society and improve people's lives. This materialistic proposal of the ideal of "equality" responds to that very ethical and historical "willingness" based on the production and development of social justice as a criterion and principle for action. Equality before the law, therefore, cannot develop its full emancipatory potentialities if it is isolated from the conditions of possibility (material/real) of human beings. The idea of equality cannot be completely achieved without predisposed actions, which develop real equality between people.

So, faced with the homogeneous and egalitarian conception of citizenship as the

8. Orestano, R., Introducción al estudio del derecho romano, Universidad Carlos III de MadridBOE, Madrid, 1997, pp. 364 and 413

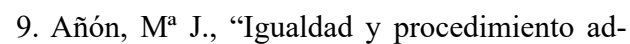
ministrativo especial para inmigrantes", Cuadernos Electrónicos de Filosofía del Derecho, $\mathrm{n}^{\circ}$ 14, 2007, p. 18. Cfr. also Igualdad, diferencias y desigualdades, Fontamara, Mexico, 2001. unique and undifferentiated predicable status of all members - who are not all subjects - of the political community, the complex reality of our societies has displayed greatly varied tendencies towards differentiation/exclusion, which translate into a structural re-adjustment of functions and/or rights within society. All we need do is look at the increasingly expeditious treatment acquired, within the internal framework of States, for example, by the regulation of immigration, in order to glimpse, on the one hand, the magnitude of the process fortification built around citizenship as a privileged status - differentiated and dualistic - visà-vis increasingly broad sectors of the population; and, on the other hand, the triumph of regulation (authority) over emancipation in a socio-economic context, whose rationality lies in the irrationality of its conditions for production.

However, this divergent tension of equality (exclusion-inclusion, regulationemancipation) is the prelude to another more essentialist tension, one that is disassociated from subjects, because it is abstracted from its material conditions of possibility, that is, from its reproduction. The result of this absolutist trend can be none other than its de-contextualisation ${ }^{10}$ from both the situation of subjects and the social processes that programmed their limits through the recognition of rights. This model of citizenship is thus separated from and moves away from any question relating to social justice and the

10. Let us say that this trend is part of the Cartesian philosophical tradition that decontextualises knowledge, to the point that knowledge can become independent of those who fostered its production. This is tantamount to ignoring the interests and experiences of those who were its producers. 
reality of citizens as subjects with genuine needs. It condenses around indisputable postulates it uses as springboards, and its descriptions are closed (dogmatic), because they block paths and retain alternatives. Its configuration is articulated following a scheme marked by a sequence that runs from fragmentation to absolutisation. Its status is ontological because its propositions are a-historical, as de-contextualised and external as its conditions of production.

When considered in these terms, this model of citizenship as a formal projection of the idea of equality condenses contradictory tendencies, but also processes of substantialisation of its contents, which are part of an absolute and reductionist logic. To talk about citizenship today is to talk about a citizenship that is built from legal-formal equality, but which is fortified behind the backs of specific subjects ${ }^{11}$. This contrasts greatly with the secular aspiration of the idea of equality, through its most substantive character: the reaction to the abstraction of the liberal State that recognises only "equality of all before the law," but ignores socioeconomic differences. Therefore, the idea of equality in its materialistic dimension

11. As Fernando Rey rightly points out, "there is an interesting paradox today: the legal concept of equality is more powerful and dense than ever, but its real validity is being devalued due to the most devastating economic crises in living memory." Rey, F., "El principio de la igualdad en el contexto de la crisis del Estado Social: Diez problemas actuales", in Presno M.(Coord.) La Metamorfosis del Estado y el Derecho, Fundamentos, Oviedo, 2014, p. 292; See also Hinkelammert F., Crítica de la razón utópica, Desclée de Brouwer, Bilbao 2002; Id., Democracia y totalitarismo, DEI., San José,1991; Id., El mapa del emperador, San José, DEI, San José, 1998; and finally, El grito del sujeto, DEI., San José, 1998. is conceived as a reflective process that has elucidated, with its social struggles for human rights, new relationships of justice and the distribution of goods in society. This is why it is linked to the problems/ needs (of people) in the space and time in which it is inserted. Hence its undeniable complexity and historicity. It means that the principles of formal and material equality are not antithetical ${ }^{12}$. Rather, they enrich and complement each other.

From this perspective, equality is a relational concept, which translates into a basic and normative duty ${ }^{13}$ to redress situations of socio-economic inequality, through actions, goods or services. It is the reflection of so-called "social rights", understood as subjective rights vis-àvis the State, not only to avoid possible normative discrimination (equality before the law), but also to receive differentiated legal treatment in view of their objective situation of social inequality.

Social rights, as a historical and conventional projection of the idea of equality, are defined as a fundamental subjective right to receive unequal and favourable legal treatment in order to obtain real equality.

12. "From a precise legal point of view, although real equality and formal equality are different concepts, (....) they cannot be contrasted (....) That is, real equality, in the social State, is placed within the conceptual framework of formal equality: real equality is a species within the formal equality genus, where a certain criterion of differentiated legal treatment in favour of disadvantaged social groups comes into play.” Rey, F., cit., p. 294.

13. A normative duty that is not limited to the inequalities arising in the interpretation of the rules alone. Regarding the normative nature of the principle of equality within our constitutional framework. See Sánchez, S. and Mellado P., El Sistema de fuentes en el ordenamiento español, Ramón Areces, Madrid, 2010, p. 102 
That is, so that the "existence" of all is feasible in terms of dignity.

Therefore, what we intend to set forth here is not a blind criticism which seeks to erase formal equality on the basis of its shortcomings, but rather a critique on the grounds that its current - formal - form is the result of the confluence of a series of different lines, which have deactivated its emancipatory nature. It is not enough to speak of equality before the law, when people are not equal in life.

\section{Towards a convergence proposal. Why it is relevant to explain the materialistic dimension of the equality principle}

The principle of equality is the starting point for a social model that, on the one hand, gives priority to the general validity of rules against the arbitrariness of those who hold power (formal equality). That is why it is set in one of the pillars that underpin the Rule of Law. However, on the other hand, it also represents, in the context of democratic systems, the idea of social justice (as a synonym for a just social order). The (formal) declaration of equality of all before the law ceases to be effective in democracy when those who should be equal before the law lack the means to fully exercise their rights.

The principle of formal equality cannot be detached from all social rights, which are, after all, its historical form of realisation. To put it another way, no action can be taken in accordance with the principle of equality independently of the realisation of all social rights, understood as rights necessary to be able to exist with dignity (i.e. as human rights). It is precisely in the complementary nature of both dimensions of the principle of equality (formal and materialistic) that the legitimacy of a fully democratic social model lies. We cannot, therefore, consider the dimensions of the idea of equality from an individualised or particularised vision (formal or substantive or vice versa); we must understand them holistically, that is, depending on the integration of their dimensions ${ }^{14}$. It is not enough to have the same rights as others, because in order to exercise them fully, the subject must be (situated) in the same conditions as others. Being able to choose, being able to exercise them, presupposes the conditions (of possibility) to be able to do so. The formal exercise of rights becomes impossible, in terms of equality, if there are no material conditions for the realisation of actions under such rights.

We can say, first of all, that the principle of equality, from its most substantive and/or materialistic dimension, is based on or underpinned by: on the one hand, respect for democracy as the only possible scenario for overcoming capitalism and for the realisation of human rights, as material conditions (modes) of possibility to live on equal terms; and, on the other hand, ideas of social justice and pluri-identity, because in them there is an historical need to equalise those who are not, do not have, cannot or do not belong.

$$
-\mathbf{I}-
$$

Democracy as an historical project has always been characterised in the political

14. Far from being opposed, they must be understood jointly. On this point, and from the perspective of our constitutional system, see Alzaga O., Derecho Político Español, según la Constitución de 1978 I, (Constitution and Sources of Law), Ramón Areces, Madrid, 2010, p. 284. 
field by the search for social justice and the distribution of power among the people. Socially just societies tend towards the real, not ritual, practice of democracy. In a context of political, social, and economic equality, no group or social class can monopolise the power-democracy tension, to the point of blocking self-government and repressing the initiatives of other people. Democracy understood as a choice of policies is the only valid idea-project for building more just and balanced, in other words, more egalitarian societies.

That is why the analysis offered here does notseek to defend liberal and parliamentary democracy, although it supports the need to take on the conquests and principles of modern democracy. But not as the great objective to be beaten; rather, as the starting point for a broader process, in which citizens can exercise their responsibilities and choose their destiny, controlling the means and participating in public life. This is not the time to look back. It is not merely a question of renovation, but of going deeper into selfgovernment and the conquest of public spaces for collective action.

Since classical Antiquity, the vigour of politics, as an historical expression of solutions to the problems of coexistence, has always been synonymous with social commitment. Few authors of the 17th and 18th centuries left Politics out of their Theodicy, their Logic, or their Treatises ${ }^{15}$. This contrasts with the scepticism or inhibition that flourishes today in our democracies. Precisely in order to restore the value of political experience as a decisive social experience, we need new

15. See Mounier E., Manifiesto al servicio del personalismo, in Obras Completas, Sígueme, Salamanca, 1992, p. 717. ideas and governments to drive them, beyond rigid pre-political conceptual frameworks, held hostage by conceptions not exposed to conflict and public debate.

It is true that representative democracy is the concept of democracy that has been globalised through hegemonic programmes of political liberalisation, but it is also true that this is an instrumental concept that aims to stabilise economic liberalisation and prevent the deterioration of institutions when faced with the effects of capitalism. Liberal consensus presupposes compatibility between economic and political liberalisation. Indeed, since the origins of representative liberal democracy, free elections and free markets have always "been regarded as two sides of the same coin." ${ }^{16}$ However, the theory of contractualism, which establishes liberal democracy, pivots on a model as hypothetical and abstract as it is decontextualised and fictional, of free, independent, individuals, equals by nature, who decide to agree and give up some rights to safeguard property, life.

The compatibility between capitalism and democracy, to paraphrase Boaventura de Sousa Santos at this point, is therefore still an open question. Even if we can

16. However, as Prof. Boaventura de Sousa rightly points out, there has been a great deal of ambiguity here. "While nineteenth-century democratic theory was concerned both with justifying the sovereign power of the State as a regulatory and coercive power and with justifying the limits of that power, the new liberal democratic consensus (converging with the neoliberal economic consensus) is only concerned with coercion. Sovereignty is not a concern, especially in peripheral States (think of Spain, Greece, Portugal, etc.), and regulatory functions are treated as a State incapacity and not as one of its powers." Sousa, B., Sociología Jurídica Crítica, Trotta, Madrid, 2009, p. 457 (parenthesis mine). 
presume this compatibility, the truth is that there are tensions between capitalism and democracy, especially when highly unequal distributions of goods and income are generated ${ }^{17}$.

The intention is not to detract from the historical importance of contractualism as the mainstay of modern individualism. Rather, it is a question of reproaching liberal democracy - as well as the representative distance of its parliamentary institutions ${ }^{18}$ - for handing over concepts such as public interest, community, or government to liberal socio-economic reproduction. In other words, the intention is to recriminate its instrumentalist profile ${ }^{19}$, which makes

17. Ibid., p. 495. See, also, as this author suggests, Haggard S., and Kaufman R., The Political Economy of Democratic Transitions, PUP, Princeton, 1992, p. 342. On the contradictions between capitalism and democracy, see R. MILIBAND, "The Socialist Alternative," in Diamond L., Capitalism, Socialism, and Democracy Revisited, The Johns Hopkins University Press, Baltimore, 1993, pp. 113 ff. See alsoBowles S., and Gintis H., Democracy and Capitalism. Property, Community and the Contradictions of Modern Social Thought, Basic Books, New York, 1986. And from a neo-Marxist perspective it is important to take into account the work of Woods E.M., Democracy against Capitalism: renewing historical materialism, Cambridge University Press, New York, 1995.

18. A division between representatives and represented that responds to an elitist perception of the democratic regime, think of Schumpeter's elitist theory. Barber B., Can America be Democratic. A Participatory Critique of the Liberal Consensus, cit., pp. 3-10.

19. Politics should be treated as philosophy, that is, through the search for knowledge for the love of itself and in itself. This is what the author himself defines as philo-policy, a term used to signify concern for politics lacking any instrumentalism - understood as a means of subjecting public actions to private purposes -, insisting on equal participation without concern for the quality of the common interest dependent on private and individual needs, or more specifically, from our point of view, on property rights conceived by contractualism. This is not surprising given that, in the background, beneath the nominal search for freedom, contractualism guided the transformation of social institutions and relations around the legal consolidation of the pillars of bourgeois liberalism: freedom, security, property, and contract fulfilment. Thus, participation and community remain at the expense of individualism.

At this point, it is easy to align with the approach taken by B.R. Barber in one of his best-known books, entitled The Conquest of Politics, analysing in depth the main liberal philosophies of today. In his view, authors such as Robert Nozick, John Rawls or Bruce Ackerman have fared well because their democratic loyalty and emancipating attitudes have responded more to the demands of the socio-cultural and historical processes of the formation of Western/capitalist modernity, than to the needs of our current political context. Under the formal legacy of claims and new rights, they have not changed anything. Thus, the same (dogmatic) conceptions of democratic power remain in force, to the detriment of the emancipation and social interest of communities ${ }^{20}$. It is precisely these authors who are accused of not having definitively liquidated this absolute way of conceiving democracy. Moreover,

participation. Id., Superman and Common Men. Freedom, Anarchy and The Revolution, Praeger, New York, 1971, p. 122. See also from the same author, Id. , The Death of Communal Liberty. A History of Freedom in a Swiss Mountain Canton, Princeton University Press, Princeton, 1974, p. 5. 20. See Id., The Conquest of Politics. Liberal Philosophy in Democratic Times, Princeton University Press, New Jersey, 1988, p. 193 
of having contributed to crystallising the socialistic project of the Enlightenment, in other words of blocking the paradigm shift required by our societies, reducing the political to mere formal reason. Or perhaps we should ask ourselves, is there a better way to naturalise the historical process, to reduce the social advancement of our communities to the development of capitalism as a system of exclusive production?

Thus, this de-democratising rationality presupposes interdependence between capitalism and democracy, two different historical processes, which came to converge and infiltrate one another ${ }^{21}$. We cannot forget, as pointed out previously, that the processes of democratisation, as processes of modernity, which proclaimed legal equality and demanded, initially at least, economic equality among all subjects, would soon become connected to individualism. This fact and the proprietary logic that gave rise to the new hegemonic socio-economic order (the bourgeois) deactivated the emancipating potential of the democratic principle. Therefore, democracy does not presuppose capitalism as its mode of production. From this perspective, the democratic system consists not so much of a government of the people, but a government of the elites, in mutual competition, in search of the legitimacy to govern $^{22}$. The elites know what is the best choice in the interests of citizens, because

21. Although "the conditions and dynamics of their development continued separately and relatively autonomously. Modernity does not presuppose capitalism as its own mode of production". Sousa, B., Sociología Jurídica Crítica, cit., p. 29.

22. In line with Shumpeter, who defines democracy as the system in which "individuals acquire the power to decide through a battle to compete for the people's vote." Shumpeter J.A., Capital- they always intervene on behalf of this purported general interest as a reflection of the popular will ${ }^{23}$.

In short, representative democracy is vulnerable. Firstly, because its stability depends, to some extent, on there being no major social inequalities, although it is not easy to glimpse at which moment and to what extent the sustained increase in social inequalities reaches breaking point so that social turmoil overflows democratic stability. ${ }^{24}$

Secondly, because the liberal public sphere establishes, as indicated earlier, the legal equality of all citizens. However, under the neoliberal model of development, powerful social agents emerge with the capacity to evade the enforcement of laws or to modify them according to their own interests ${ }^{25}$. Furthermore, the increasing criminalisation of public life ${ }^{26}$ and the emergence of new

ismo, socialismo y democracia, Folio, Barcelona, 1984, p. 383.

23. An interest, on the other hand, marked by the external influence of corporations in the policies advocated by the representatives of citizens in their respective chambers. Which makes democracy a plutocracy. See Parenti M., Democracy for the Few, St. Martin's Press, New York, 1988, p. 36. Only they believe they know and can interpret something as objective and timeless as national political truth. Today, however, nobody is guaranteeing that the decisions made are the right ones. But what is even worse is that they are taken by elites for and in their own interests. In this regard, see Parameswaran M.P., "Democracy. Participatory Democracy", in Fisher W.F., and Ponniah T., (ed.), Another World is Possible, Zed Books, New York, 2003, pp. 324-328.

24. See Sousa, B., Sociología Jurídica Crítica, cit., p. 504.

25. Ibid.

26. See Ibañez, P., Corrupción y Estado de Derecho. El papel de la jurisdicción, Trotta, Madrid, 1996, pp. 103-109. 
phenomenologies of the illegality of power have given way "to neo-absolutist forms of public power, lacking limits and controls and governed by strong hidden interests, within our systems."27

And, finally, because of the subordination of the Nation-State to multilateral bodies, in an ever-increasing "proportional transfer of power", influence has been taken away from classic decision-making and representation bodies in liberal electoral polyarchies or representative democracies, in other words, from parliaments ${ }^{28}$. The principle of equality, under the liberal representative scheme, thus becomes an unpragmatic principle.

Participatory democracy, on the other hand, is a (counter-)hegemonic conception of democracy. From the perspective of

27. Needless to say, this phenomenology contributes to the crisis of democracy, since it "amounts to a crisis of the principle of legality, that is, of the subjection of public powers to the law, on which both popular sovereignty and the paradigm of the Rule of Law are founded". Ferrajoli L., Derechos y garantías. La Ley del más débil, Trotta, Madrid, 1999, pp. 15 and 17.

28. See on this point Barber B., "Making Democracy Strong," in Murchland B., Voices in America. Bicentennial Conversations, Prakken, Ann Arbor, 1987, p. 170-171. This author opposes John Naisbitt's thesis, which posits that corporations are becoming more democratic. According to Barber, it is as if absolutism became more democratic because Louis XIV consulted courtiers before hanging a peasant. For this author, some things might be happening incidentally, but this does not mean accepting decisive structural changes. In fact, nothing has changed, and corporations pose a growing threat to democracy. In this regard, see. Id., Superman and Common Men. Freedom, Anarchy and The Revolution, cit., pp. $105 \mathrm{ff}$. For the American author, the market is dominated by a series of hierarchically organised corporations capable of manipulating politics to their whim. participatory democracy, representative democracy is only an incomplete - not altogether erroneous - conception of democracy. Moreover, it is the starting point. The central difference between the two lies precisely in the denial of this supposed compatibility between democracy and capitalism. It is not sustainable and, in the event of a collision between both processes, democracy must prevail. The basic cognitive idea of participatory democracy is that capitalism inflicts systematic damage on most populations. Participatory democracy is less procedural, but more substantive than representative democracy. It focuses more on the distribution of power and the search for social justice than on governance ${ }^{29}$. Indeed, classical political values - freedom, pluralism, polytheism of values, equality - abandon their most instrumental meaning and thus acquire a more energetic index under the idea of common participation. Democracy consists of this. Democracy is a practice that is based on nothing less than common action, common work, and the common construction of new possibilities.

Participatory democracy, therefore, is antagonistic to capitalism ${ }^{30}$. Only in

29. Sousa B., Sociología Jurídica Crítica, cit., p. 497.

30. See Miliband R., Socialism for a Sceptical Age, Polity Press, London 1995, pp. 6 ff. In this book, he develops the idea that capitalist democracy is a contradiction in terms. From this perspective, socialism has two objectives: (i) to go further in the democratisation of society than any representative democracy could permit; (ii) the radical alleviation of the immense inequalities present in societies. Democracy, equality, and cooperation would be the fundamental principles upon which this action would be based. For this author, the fact that a small number of people appropriate the resources and, therefore, the means 
democracy, with its struggles and social practices, does the political value of the community make sense. Because only from the immediate reality of people, from the historicity (finiteness) of their social conditions, can the real (effective) equality of all subjects be built.

\section{- II -}

However, despite this disposition that builds (historical) reality based on the production and development of democracy as a criterion and principle for action $^{31}$, the facts are now very different. Therein lies poverty, the concentration of wealth in a few hands, unemployment, the decline in quality of life indicators, precarious employment, and the general increase in social inequalities. Democracy cannot deploy its emancipating potential if it is abstracted from the (material/ real) conditions of citizens. This is precisely another problem we intend to highlight here: to elucidate why current democratic regimes have been unable to articulate a comprehensive system of guarantees for social rights. Even more broadly, why, in the contexts of today's globalisation (markedly neoliberal in its strategy), democracy has been paralysed and even displays significant setbacks in terms of citizens' demands for a more inclusive and emancipating system. The idea of democracy cannot be completely

of production, which also reproduce the established order, is a serious injustice.

31. Understanding historical reality to be the only reality to which we have access as subjects. This is not a reduction of the idea of reality, but rather a significant way of understanding it, in terms of human life, since it is, after all, the only reality into which all human beings are ground. See Ellacuría I., Filosofía de la realidad histórica, UCA Editores, San Salvador, 1990. achieved without predisposed actions, which develop real equality between people.

It is at this point that the idea of social justice becomes essential. Only through social justice can all types of social inequality/marginalisation be addressed. Relations of social inferiority or discrimination cannot be classified into stagnant compartments. They must be treated in a relational way, because we cannot fight against one without taking on all the others. From this perspective, social justice has been one of the classic demands of the Left throughout its history. However, despite this, the idea of social justice remains, to some extent, vague, so it is necessary to make a commitment to the rigorous and scientific realisation of the scope and meaning of social justice.

The idea of equality is, therefore, closely related to the idea of social justice. The egalitarian society is a socio-philosophical idea that attributes to all people the same rights, identical responsibilities, and equal opportunities in all spheres of life: (i) in the control of resources, in the organisation of work and production; (ii) in the distribution of goods, services, and rights; and (iii) in government and the social reproduction of order. The notion of equality presupposes a distribution of goods, responsibilities, and rights according to individual differences and "all" existing needs.

A society will be just or unjust based on the guiding principles (value tables) of human behaviour and social relationships derived from judgements about the results of our historical condition. After all, values are not independent or autonomous, but refer to the facts we value and are expressed in the words, or assessments, with which we 
refer to those facts. To the extent that we are subjects of the realities that we assess, we participate in a certain conception of the world and order our actions according to principles, that is, according to the idea of relevance. Any statement of equality, to paraphrase Ruiz Miguel on this point, "necessarily presupposes an implicit evaluative component after the criterion of comparison, for the simple reason that such a criterion contains the idea of relevance in the relationship of equality that is described or prescribed" 32 .

From this perspective, a society is just, therefore, when the productive resources, knowledge, work, goods, and services of the community are channelled into meeting the intrinsic needs of all people, so that we all have and can exercise the same rights and responsibilities.

Equality of "all" is the necessary basic judgement of just societies. And it only takes place when all people can, first, live and then be free to develop their capacities and initiatives, using productive resources and knowledge accumulated in socially significant productive efforts ${ }^{33}$. The equality of all thus becomes a necessary ethic, which dissolves the abyss between 'being' and 'ought to be', since it is postulated on the basis of a judgement of

32. The idea of relevance necessarily implies the introduction of an evaluative criterion - in the broad sense of this word, "not necessarily moral - since the selection of a trait as a criterion of comparison comes from a consideration of what is highlighted, that is, significant or important in a given context". Ruíz Miguel, A., "Sobre el concepto de igualdad", cit., p.51.

33. The "real" wealth of the human species does not lie in the mere juxtaposition and/or concentration of private controlled capital, but in the aggregate of human potential developed through the principles of social evolution. existence under conditions of equality, for in order to be able to postulate any ethics the subject who does so must, first, live in "conditions of possibility to continue doing so". The "relevance criterion" lies in the affirmation of life under "conditions of equality," which become something like the necessary basic judgement - its assumption - that feeds any ethics. To the extent that it is a judgement of existence, from the very contingency of the subject, this reproductive rationality and the ethics to which it is harnessed do not come from any absolute or transcendental instance ${ }^{34}$, nor do they lend themselves to dogmatic processes $^{35}$. That is why we say that the idea of equality is essentially materialistic.

Material equality has been a reflective process that has elucidated, with its social struggles, new relations of justice and the distribution of goods in society. This is why it is linked to the problems/needs (of

34. By "transcendental", we understand the process by which human beings, as cognitive subjects, formulate categories.

35. The duty to live (necessary ethics) is necessary even in order to have duties and rights. It is therefore a way of "arguing through premises, not through constrictive logic derivation." Solórzano N., Crítica de la Imaginación Jurídica. Una Mirada desde la epistemología y la historia al derecho moderno y su ciencia, Universidad Autónoma de San Luís de Potosí, San Luís de Potosí, 2007, p. 220. As this author rightly points out, "overcoming the essentialist-like iusnaturalist positions, would that ethical duty, linked to human action and, therefore, to concrete, historical praxis, not be destined to operate as material criterion and material principle for law as well? The duty of the norm is un-necessary; it only emerges through the normative effect. But there is a broader duty: the duty to live (necessary ethics), which is necessary even to be able to have duties." (Ibidem). See Dussel E., Ética de la liberación en la edad de la globalización y la exclusión, Trotta, Madrid 1998. 
people) in the space and time in which it is inserted. Hence its undeniable complexity and historicity ${ }^{36}$. After all, the democratic principle, insofar as it defines the limits of what can or cannot be decided, places social justice as a requirement for action.

On the other hand, the rigidity with which human identities are defined and fortified operates as a factor of segregation that isolates people and pits them against one another, through the absolutisation of identity factors that fragments human groups. Something that should not surprise us, since, after all, one of the most significant issues in the instrumental rationality enshrined in capitalism is precisely this fragmentary and/or separatist character, which sects and segments, rather than pluralises (the fragment is only a fragment as part of a whole). The opposite, the plural, is not fragmentary, but the multiple sum of (complementary and relational) all. Thus, this mode of domination with its "nostalgia of the one" ${ }^{37}$ or of the dominant identity smothers any type of affiliation and proscribes any plurality, but, in turn, it silences that fact in the fragmentation of the identity already built, and to prevent plurality from emerging, it tars it with the brush of irreconcilable contradiction.

Of course, fragmenting does not amount to multiplying, but rather is synonymous with disintegration and division. It is not

36. "The criterion of relevance has a conceptual part, which comes from universalisability that excludes proper names and defined descriptions, and a contextual part, which depends on variable culturally developed conceptions about equality." Ruiz Miguel A., "Sobre el concepto de igualdad", cit., p. 64

37. Ibañez J., Más allá de la Sociología. El grupo de discusión: técnica y crítica, Siglo XIX, Madrid, 1986, pp. 58-59. plural, because it does not add; it only divides. On the other hand, the plural is not fragmentary, because it is synonymous with one and others. This means that the complexity of pluralistic groups and their multiple loyalties disappears when just one affiliation is attributed to a person. This reductionism of group understanding not only proscribes any possibility of plural construction of identity, but also absolutises the given identity of the group, until it becomes exclusive and exclusionary.

In short, a greater understanding of the plural character of human identity is essential for a convincing and realistic project of social transformation. Recognising that identities overlap is essential to maintaining a political attitude that does not fall into the trap of fundamentalism, because all of them are valid in their context, provided they do not try to supplant others. Transformations in the world of work (immaterial work, living work), the rupture with modern inertia, the influence of feminist currents, the need for intercultural inclusion, environmentalism... these are elements that we cannot forget. But this recognition should always be realised as a means of articulating a common body (pluriversion of reality) that aims to fight the oppressions that give these movements reason to exist. Confronting today's challenges in a fragmented and partisan manner is a very serious mistake. It is very important to understand that only through the organisation and conception of an inclusive movement is social change possible ${ }^{38}$. Pluri-identarian consciousness becomes decisive here. An understanding of the diverse, as an expression of human

38. Albert M., Cagan L., Liberating Theory, South End Press, Boston, 1986, pp. 143-145. 
richness, must be the means to articulate an encounter in the shared, the common.

\section{A few answers}

At this point, and for our purposes here, on the ground that a satisfactory answer to the problem of equality has not been provided via the legal route, we have sought to spell out some of the ways we might overcome the stagnation affecting the notion of equality in Western democratic systems, and then venture a few answers.

The democratisation (equality and pluralism) of life and social relations has always been the secular aspiration of Western societies. It is this egalitarian demand that provides the key to designing social initiatives and class-war practices, which would ultimately transform the socio-legal configuration of order, through the recognition of new spaces and new rights. However, the search for "equality" in our democracies, with its undeniable contributions and revolutions, has today entered a difficult phase of doubt and stalemate, largely owing to the reductionist and ideological use of it.

The idea of equality, as it has been shaped in modern societies, has two sides or dimensions: one legal/formal, the other materialistic. The first is summarised in the principle of equality "of all subjects" before the law. It is the most important one in our normative systems and is defined as a subjective right of all citizens vis-à-vis the State. However, the formal dimension of equality diminishes the problem of the effectiveness of rights to a consideration of normative efficiency, by isolating them from the other dimensions of reality, including the conditions that enable equality to be achieved. The second, in contrast, responds to that historical need for "human beings" to "exist," with "material conditions of possibility" - as critical theory has pointed out - that is, so that they can continue to do so. The idea of equality, in its materialistic dimension, has marked the meaning of social struggles for human rights (understanding these not only as rights, but as means/ways of life).

Equality, therefore, as a historic process of human emancipation, transcends the strictly legal/formal plane. Furthermore, it is enhanced by the "historic" willingness to democratise society and improve people's lives. This is the materialistic dimension of the principle of equality, this ethical and historical "willingness" based on the production and development of social justice as a criterion and principle for action. Human rights and democracy, with their fighting practices and traditions, cannot be understood today without the idea of equality as a necessary principle, of equal distribution of power and wealth among and for the people.

Therefore, the critique developed here involves this historical contextualisation ${ }^{39}$ of the idea of equality, in an effort that also leads us to try and elucidate its true genealogy. Human rights have always been linked to processes of reaction

39. "Social science, which is condemned to critical rupture with the first evidence, has no better weapon to carry out this rupture than historicisation that allows it to neutralise, theoretically at least, the effects of naturalisation and, in particular, the amnesia of the individual and collective genesis of a datum that is presented with all the appearances of nature and demands to be accepted without discussion, taken for granted. Bourdieu P., Meditaciones Pascalianas, cit., pp. 153 and 239. 
against inequalities. They have been and remain a reaction to any kind of oppression and/or domination, because human rights, which are rights and are human, are always actions that refer to human beings in need. The fact that they were formally conceived under the umbrella of normative reasoning does not presuppose that they should be conceived exclusively as individual rights ${ }^{40}$, which demand fulfilment in the future, or even as horizons of possibility (idealistic vision), but as a ways of life that make human existence - dignified existence feasible for all people ${ }^{41}$.

The idea of equality is, therefore, not possible without this material judgement of existence. Thus, the utopian idealism of those who advocate an absolute vision of human rights, which reduces them to mere - unachievable - prescriptive horizons, can be confronted, since what we actually do are actions in accordance with values, and these are always contingent, as are the historical forms in which they are objectified (through institutions, rules, etc.). It is precisely here

40 , For human rights, then, could not be thought of in any other way than through the paradigms in force, that is, through the doctrine of subjective rights. That is why human rights are beginning to be imagined exclusively as the rights of individuals, of (bourgeois) citizens, that is, as individual rights.

41. Then, "the extraction of equality as a principle for the construction of the State, as well as its recognition of law in the international standard, has also led to its recognition in the international human rights protection system, part of the ius cogens, permeating and sustaining the national and international system, both in its demand to respect and ensure equality among persons, and in the abstention from unequal treatment without justification" Inter-American Court of Human Rights. Nadege Dorzema et al. v. Dominican Republic. Ruling of 24 October, 2012, paras. 225226. (Italics are not in the original) that we come to the conclusion that acting in accordance with human rights involves acting to meet the needs of these human beings as subjects who are truly in need.

This being the case, if we intend to go beyond the boundaries of the modern forms of the principle of equality (formal equality), the next step is to reconstruct paradigmatically the categorisation processes that have been followed (functional to the iuspositivist paradigm and systematisation of general theory), through alternative rationality frameworks (reproductive rationality), which return to the modern lines that remained hidden. For the time being, it is enough to outline the pillars on which the principle of equality is based, through its most substantive or materialistic dimension: on the one hand, strengthening participatory democracy - as the only possible scenario for overcoming capitalism - and human rights, understood not only as material conditions (modes) of possibility in order to live, but as the decisive axis for the design of a new epistemological and paradigmatic approach; and, on the other hand, the ideas of social justice and pluriidentity, for in both of them there is a historical need to equalise those who do not or cannot have ${ }^{42}$.

\section{Bibliografy}

Albert M, Cagan L., Liberating Theory, South End Press, Boston, 1986

Alzaga O., Derecho Político Español, según la Constitución de 1978 I, (Consti-

42. A preliminary overview of the approaches proposed in this paper has been published in Spanish in Derechos y Libertades, $n^{\circ} 36$, Epoca II, 2017, pp. 55-89 
tution and Sources of Law), Ramón Areces, Madrid, 2010

Añón, $\mathrm{M}^{\mathrm{a}}$ J., Igualdad, diferencias y desigualdades, Fontamara, Mexico, 2001.

Añón, $M^{a}$ J.,, " Igualdad y procedimiento administrativo especial para inmigrantes", Cuadernos Electrónicos de Filosofía del Derecho, n 14, 2007, p. 18.

Aristotle, Politics III, 9, 1280a

Barber B., Superman and Common Men. Freedom, Anarchy and The Revolution, Praeger, New York, 1971.

Barber B., The Death of Communal Liberty. A History of Freedom in a Swiss Mountain Canton, Princeton University Press, Princeton, 1974.

Barber, B., "Making Democracy Strong," in Murchland B., Voices in America. Bicentennial Conversations, Prakken, Ann Arbor, 1987.

Barber, B., The Conquest of Politics. Liberal Philosophy in Democratic Times, Princeton University Press, New Jersey, 1988

Barry P., Ser ciudadano, (translated by A. Mendoza from the original Deep Citizenship, Pluto Press, 1996) Sequitur, Madrid, 1999.

Bowles S., and Gintis H., Democracy and Capitalism. Property, Community and the Contradictions of Modern Social Thought, Basic Books, New York, 1986.

Didier, M., El principio de la lgualdad en las Normas Jurídicas, Marcial Pons, Buenos Aires, 2011.

Dussel E., Ética de la liberación en la edad de la globalización y la exclusión, Trotta, Madrid 1998.
Ellacuría I., Filosofía de la realidad histórica, UCA Editores, San Salvador, 1990.

Ferrajoli L., Derechos y garantías. La Ley del más débil, Trotta, Madrid, 1999.

Fisher W.F., and Ponniah T., (ed.), Another World is Possible, Zed Books, New York, 2003.

Herrera, J., "Legalidad: Explorando la nueva ciudadanía", in Campos de juego de la ciudadanía, Various Authors, EI Viejo Topo, Barcelona, 2003.

Hinkelammert F., Crítica de la razón utópica, Desclée de Brouwer, Bilbao 2002; Id., Democracia y totalitarismo, DEI., San José,1991; Id., El mapa del emperador, San José, DEI, San José, 1998; and finally, El grito del sujeto, DEl., San José, 1998.

Ibañez J., Más allá de la Sociología. El grupo de discusión: técnica y crítica, Siglo XIX, Madrid, 1986.

Ibañez, J., Corrupción y Estado de Derecho. El papel de la jurisdicción, Trotta, Madrid, 1996.

Miliband, R., "The Socialist Alternative," in Diamond L., Capitalism, Socialism, and Democracy Revisited, The Johns Hopkins University Press, Baltimore, 1993.

Miliband, Socialism for a Sceptical Age, Polity Press, London 1995

Mounier E., Manifiesto al servicio del personalismo, in Obras Completas, Sígueme, Salamanca, 1992.

Orestano, R., Introducción al estudio del derecho romano, Universidad Carlos III de Madrid-BOE, Madrid, 1997.

Parenti M., Democracy for the Few, St. Martin's Press, New York, 1988. 
Rey, F., "El principio de la igualdad en el contexto de la crisis del Estado Social: Diez problemas actuales", in Presno M.(Coord.) La Metamorfosis del Estado y el Derecho, Fundamentos, Oviedo, 2014.

Ronconi L.\&Vita, L., "El principio de igualdad en la enseñanza del Derecho Constitucional", in Academia. Revista sobre enseñanza del Derecho, Buenos Aires, $n^{\circ}$ 19, 2012.

Sánchez, S.\&Mellado P., El Sistema de fuentes en el ordenamiento español, Ramón Areces, Madrid, 2010.

Scuccimarra L., I confini del mondo, II Mulino, Bolonia, 2006.

Sousa, B., Sociología Jurídica Crítica, Trotta, Madrid, 2009, p. 457

Shumpeter J.A., Capitalismo, socialismo y democracia, Folio, Barcelona, 1984.

Solórzano N., Crítica de la Imaginación Jurídica. Una Mirada desde la epistemología y la historia al derecho moderno y su ciencia, Universidad Autónoma de San Luís de Potosí, San Luís de Potosí, 2007

Woods E.M., Democracy against Capitalism: renewing historical materialism, Cambridge University Press, New York, 1995. 


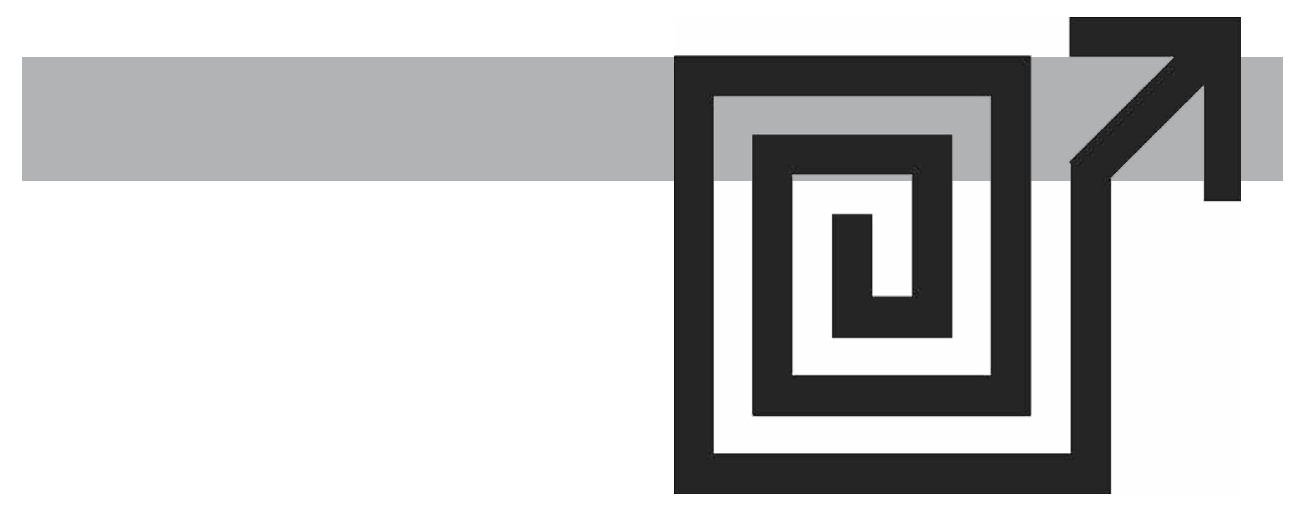

Inéditos

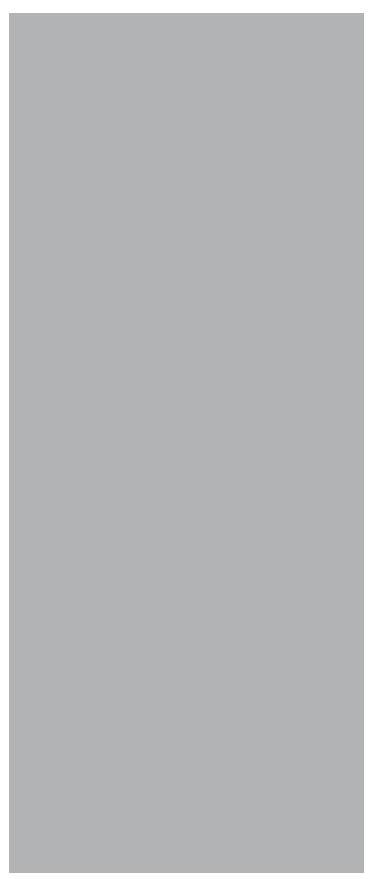


